\title{
Analysis of the Effects of the Banking Sector Consolidation on the Real Sector of the Nigerian Economy
}

\author{
Sama'ila Idi Ningi \\ Accounting and Finance Technology Programme School of Management Technology Abubakar Tafawa Balewa \\ University, Bauchi
}

\begin{abstract}
This study sets out to analyze the effects of the banking sector consolidation in financing the real sector of the economy in order to find out if the problem of underfunding of the real sector of the Nigerian economy still exists five years after the Banking Sector Consolidation. The research through literature review and comparative analysis of secondary data from Central Bank of Nigeria (CBN) like CBN Statistical Bulletin, and Nigerian Deposit Insurance Corporation (NDIC) Annual Reports found that commercial banks sectoral allocation of loans and Advances to the real sector of Nigerian economy increased considerably over the five years after the consolidation. The study also found that the deposit base of commercial banks increased considerably over the five years period following the banking consolidation in 2005. The result also shows that commercial banks capacity to fund the real sector of the economy increased considerably after the banking sector consolidation. The commercial banks have been strengthened to perform their intermediation role through increase in their deposit base following the consolidation exercise. The Federal Government through the Central Bank of Nigeria (CBN) should encourage commercial banks to continuously increase their funding of the real sector of the economy especially Agriculture, Manufacturing, (Textile industry) and Small Scale industries which constitute the engine of growth of the economy
\end{abstract}

Key Words: Banking, Consolidation, Real Sector, Nigerian Economy

\section{Introduction}

The Banking industry is the life wire of any economy. It is the sector that drives other sectors of the economy because of its intermediation role. It is not possible for any meaningful development to take place in any economy without an effective and efficient Banking system. Banks in their intermediation roles act as agents of development by mobilizing funds from surplus sectors of the economy for on-lending to the deficit sector (Diamond, 1984; Boyd and Prescot, 1986 and Ningi and Dutse, 2008).

Sanusi (2010) states that Surveillance Report of Central Bank of Nigeria (CBN) as at end-March 2004 revealed that 62 banks out of 89 were classified as sound and satisfactory while 14 were classified as marginal. According to CBN Surveillance Report, the number of unsound banks rose from 9 as at end-December 2003 to 11 in May 2004.

Sanusi (2010) also argues that apart from being under-capitalized, the banking industry was characterized by several weaknesses which include poor corporate governance, poor asset quality, inaccurate reporting and non-compliance with regulatory requirements, gross insider abuses resulting in huge nonperforming insider related credits and lack of capacity to support the real sector of the economy. That is why Ningi and Dutse (2008) pointed that the benefits of consolidation would materialize only if the authorities work diligently to ensure that past weaknesses do not continue in post consolidation era.

Sanusi (2010) further posits that Bank consolidation exercise was meant to address these weaknesses through recapitalization of banks with minimum paid-up capital of N25 billion, ensuring minimal reliance on public sector for funds, adoption of risk focused regulatory framework and stricter enforcement of corporate governance principles of banking.

Oboh (2005) believes that Banks in carrying out their financial intermediation role of matching the interest of depositors with those of borrowers by providing a coordination function for the two groups. According to Sanusi, (2010), one of the problems the banking sector consolidation was meant to address was the lack of capacity of the banking industry to support the real sector of the economy. Banks capacity to support the real sector of the economy by granting of loans can only result from increase in the deposit base of banks from where such lending could be granted. Adegbaju and Olukoyo (2008) all agreed that the main objective of the banking Sector Reform is to move the Nigerian economy forward and to position the banking system to perform their developmental role of enhancing economic growth which will subsequently lead to improved overall economic performance and societal welfare.

The economy cannot go forward unless the real sector of the economy is financed by banks through the extension of credits from the deposits mobilized by the banks. In line with various arguments this study is aimed 
at analyzing the effects of consolidation on commercial banks regarding the financing of the real sector of the economy and the intermediation role of banks.

\section{The Importance of Commercial Banks in the Economy}

Sanusi (2011) argues that due to the critical role banks play in the economy coupled with the fact that the ability of the banks to effectively impact on economic development depends on their soundness and efficiency, government all over the world continue to take various measures to safeguard the banking sector through reforms. Lin (2009) in his argument shows that low income countries should make small, local banks the bedrock of their financial systems. The backdrop of his argument is centred on the seeming need to support the competitive sectors of the economy which according to Lin (2009) are not in congruence with the size and sophistication of banks found in the developed world.

According to Sanusi (2011), such reforms in the banking sector focus on increased risk management procedures and enhanced corporate governance which aims at strengthening and repositioning the banking industry to enable it contribute effectively to the development of the real sector through its intermediation role. Banking reforms in form of consolidation and recapitalization was intended to grow banks and position them to play an important role in driving the development in other sectors of the economy.

Soludo (2005) describes the Nigerian banking system as fragile and marginal. He posited that the banking system was facing enormous challenges which if not addressed urgently will snowball into a crisis in the future. He identified the problem of banks as persistent liquidity problem, unprofitable operations and weak asset base. The indifference shown by banks to small savers has compounded the problem of low domestic savings and high bank lending rates in the country. This according to him has consequently reduced access to relatively cheap and stable funds that could provide a reliable source of credit to the productive sector at affordable rates of interest.

\section{Banking Sector Consolidation}

According to sloan and Arlond (1970) consolidation is a fusion of the assets and liabilities, in whole or in part of two or more business establishment. Consolidation represents the idea of investment and the coming together of firms; it can also mean larger sizes, larger shareholder bases and larger number of depositors. Bank or corporate consolidation could be achieved by way of mergers/acquisition and recapitalization. And to Somoye (2008) it is more than mere shrinking of number of banks in any banking industry.

According to Hall (1999) consolidation is a global phenomenon, which started in the advanced economies of the world. For example, the enactment of Riegle-Neal Act, which allows interstate branch banking beginning from 1997 this led to increase in bank mergers in the USA (Akhavin et al and kwan 2004). Consolidation allow a mega bank to enjoy higher profit, increase revenue and low problem loans. Japanese banking industry also experienced consolidation in the 1990s which resulted to economies of scale (Fukuyama, 1993; Mckillop et al 1996). Consolidation in financial services in the USA and other industrialized countries has occurred along 3 lines, namely: within the banking industry, between banks and other non-bank financial institutions, and across national borders. In the USA, most of the consolidation that took place occurred within the banking sector, for instance, in that country, the number of banking organizations fell from about 12,000 in the early 1980s to about 7,000 in 1999, a decrease of more than 40\%.In Canada, there has been trend toward consolidation of commercial banks and merchant banks, whereas in Europe, where the universal banking model is more prevalent, the trend has been to combine banking and insurance business. While most of the bank consolidation in the developed economies occurred within the domestic front, there are signs of increased cross boarder activities. Such cross boarder activities have been facilitated in Europe with the lunch of the euro. The trend towards financial consolidation in Europe, USA and Canada could be traced to several factors such as (1) the need to eliminate week or problem financial institutions during the thrift and banking crisis of the late 1980s and early 1990s (2) some European countries experience problems with institutions weakened by exposure to real estate lending (3) advancement in telecommunication and information technology has also accelerated the face of bank consolidation. It has reduced the cost of providing financial services (Adeyemi, 2005).

According to Adegbajo and Olokoyo (2008) recapitalization means increasing the debt stock of the company or using additional shares through existing shareholders by way of right issues or new shareholders. They argued that recapitalization can even be in form of merger and acquisition or foreign direct investment. To Soludo (2004) in Nigeria banks have abandoned their main function of financial intermediation to focus on quick profit ventures, such as trading in foreign exchange, import - export trade instead of manufacturing and over dependence on public sector fund for their deposit base. This according to him necessitated the bank reforms in form of recapitalization.

That is why CBN induced the bank consolidation in Nigeria. It was intended to reduce the number of banks, create economies of scale and improve credit risk and technology. Market induced bank consolidation 
which is common in developed economies like Europe and America holds the promise of economies of scale, operational efficiency, profitability and resource maximization.

\section{Gains of Banking Sector Consolidation in Nigeria}

Sanusi (2011) argue that one of the positive outcomes of consolidation on commercial banks in Nigeria was that the merged banks by virtue of their size were empowered to finance big projects especially in the infrastructure, oil and gas sectors through the new window of enlarged single obligor limits. According Ikpefan, (2012) the large size of the merged banks engenders customer confidence and reduced the fear of bank distress in the mind of the general public. The number of bank branches has increased significantly from 3,247 as at 2003 to 5,014 branches as at December 2009. And further to over 5,837 in 2010 (Sanusi, 2011) thereby improving access to finance. The capital market in Nigeria grew as a result of consolidation as many banks made successful outing in their Initial Public Offers (IPDs). The consolidation exercise had a positive impact on the payment system due to the reduction of banks which made it possible to deploy the new automated clearing system and also reduced the length of time for payment of clearing cheques (Sanusi, 2011).

\section{Post Consolidation Problems in Nigeria.}

Sanusi (2011) argue that the positive gains made from the consolidation exercise did not last for long as new problems emerged in the banking sector in 2008 which was triggered off by the global financial crisis. The increase in the capital base of merged banks coupled with poor corporate governance led the merged banks to engage in high risk ventures like creation of margin loans and other high risk investments.

According to Sanusi (2011) in analyzing the post consolidation problems of commercial banks stated that the crisis in the capital market which reared its ugly head in 2008 led to the depletion of the balance sheet of banks to the extent that some of the banks had to depend on CBN for life line in order to remain afloat. Interbank interest rate increased as some distress banks had to borrow at any rate from the inter-bank sector in order to remain afloat. He went further to state that the crisis brought about increase in the number and volume of nonperforming loans. The fear of bank distress and stability of the banking system which was prominent among stakeholders and general public prior to the consolidation exercise in 2004 re-emerged in 2008. There were also issues of unethical conduct and corporate governance among the managements of banks at this period (Ikpefan, 2012).

\section{On-going Banking Reforms in Nigeria}

Sanusi (2010) in analyzing the on-going banking sector reforms posited that the CBN in 2009 adopted three methods in examining the financial conditions in the 24 commercial banks in Nigeria. According to him the first approach was the special examination of the banks jointly carried out by CBN and NDIC. The first examination of the twenty four (24) commercial banks in Nigeria revealed that there were problems of capital adequacy, liquidity crisis, lack of corporate governance, and risk management problems in nine (9) out of the twenty-four (24) banks in Nigeria. The 9 banks failed to meet the 10 percent capital adequacy ratio, and the twenty-five (25) percent minimum liquidity ratio. The nine banks had huge volume of non-performing loans and their exposure to gas and oil sector as well as margin loans were high (Ikpefan, 2012).

Sanusi (2010) stated that the second method adopted by CBN in examining the financial condition of the banks was the appointment of independent consultants. The result of the independent consultants revealed that the nine banks were in far worse condition than that of the CBN special report. The report of the independent consultants revealed that the nine banks in question were technically insolvent with significant negative assets. The report also revealed several illegal activities that were perpetrated in five out of the nine distressed banks.

According to Sanusi (2010) the third method was the management account audit of the banks. The outcome adopted by $\mathrm{CBN}$ in examination of the financial conditions of banks was their directive to the newly appointed management team of the banks to carry out the management account audit which revealed the same lapses in the audit report previously carried out by independent consultants.

\section{Sectoral Distribution of Commercial Banks Loans and Advances (2000 - 2010)}

The real sector of Nigerian economy is considered in this context to be agriculture, forestry \& fishery, manufacturing, and mining. the period considered in this research work include sectoral allocation of commercial banks loans and advances five years before the banking sector consolidation (2000-2004) and five years after the banking sector consolidation $(2006-2010)$ using 2005 as the base year. 
Analysis of the Effects of the Banking Sector Consolidation on the Real Sector of the Nigerian

\begin{tabular}{|c|c|c|c|c|c|c|}
\hline Years & $\begin{array}{l}\text { Agric, } \\
\text { Forestry \& } \\
\text { Fishery. }\end{array}$ & Manufacturing & $\begin{array}{l}\text { Mining \& } \\
\text { Quarry }\end{array}$ & Total & $\begin{array}{l}\text { Increase/ } \\
\text { Decrease }\end{array}$ & $\begin{array}{l}\% \\
\text { Increase/ } \\
\text { Decrease }\end{array}$ \\
\hline 2000 & $41,028.9$ & $141,294.8$ & $32,288.6$ & $214,612.3$ & & \\
\hline 2001 & $55,846.1$ & $206,889.0$ & $70,477.1$ & $333,212.2$ & $239,919.7$ & 42 \\
\hline 2002 & $59,849.7$ & $233,474.7$ & 70,170 & $363,494.4$ & $209,637.5$ & 36 \\
\hline 2003 & $62,102.8$ & $294,309.6$ & $95,976.4$ & $452,388.8$ & $120,743.1$ & 21 \\
\hline 2004 & $67,738.6$ & $332,113.7$ & $131,055.6$ & $530,907.9$ & $42,224.0$ & 7 \\
\hline 2005 & $48,561.5$ & $352,038.3$ & $172,532.1$ & $573,131.9$ & - & - \\
\hline 2006 & $49,393.4$ & $445,792.6$ & $251,477.1$ & $746,663.1$ & $173,531.2$ & 30 \\
\hline 2007 & $149,578.9$ & $487,576.0$ & $490,712.9$ & $1,127,867.8$ & $554,735.9$ & 97 \\
\hline 2008 & $106,353.8$ & $932,799.5$ & $846,942.8$ & $1,886,096.1$ & $1,312,964.2$ & 229 \\
\hline 2009 & $449,475.1$ & $3,969,542.4$ & $3,979,176.4$ & $8,398,193.9$ & $7,825,062$ & 1,365 \\
\hline 2010 & $591,982.7$ & $3,867,800.5$ & $5,314,276.1$ & $9,774,059.3$ & $9,200,927.4$ & 1,605 \\
\hline
\end{tabular}

Source: CBN Statistical Bulletin (2010)

According to Table.1, in 2006 commercial banks sectoral allocation of loans and advances to agriculture, manufacturing and mining increased by N831.9M (2\%), N93,754.3M (26\%) and N78,945M (46\%) respectively when compared to commercial banks allocation of loans and advances to these sectors in 2005 .

In 2007, commercial banks loans and advances to agriculture, manufacturing and mining increased by N101, $017.4(208 \%), \mathrm{N} 135,537.7$ (38\%), N318, 180.8 (184\%) respectively when compared with loans and advances allocated to these sectors in 2005. In 2008, commercial banks loans and advances to agriculture, manufacturing, and mining sectors increased by N57,792.3M (119\%), N580,761.2M (165\%) and N674,410.7M (391\%) respectively when compared with 2005 allocation of commercial banks loans and advances to these sectors. In 2009, commercial banks loans and advances to agriculture, manufacturing and Mining increased by N400,913.6M (825\%), N3,617,504.1M (1027\%), and N3,806,644.3M (2206\%) respectively when compared with the commercial banks credit allocation to these sectors in 2005.

In 2010, commercial banks loans and advances allocation to agriculture, manufacturing and mining increased by N543,421.2M (1119\%), N3,515,762.2M (998\%) respectively when compared with commercial Banks allocation of loans and advances to these sectors in 2005.

ii. The second aspect of data presented in this research work is based on extracts from NDIC annual reports on key macroeconomic indicators displaying the total deposits of commercial banks from 2000 to 2010. The period covered by the research indicate total deposits of commercial banks five years before the banking sector consolidation (2000 - 2004) and five years after the banking sector consolidation (2006 - 2010) using 2005 as the base year.

Table 2: Deposit of Banks in Nigeria (N'Billion)

\begin{tabular}{lll}
\hline Year & $\begin{array}{l}\text { Total Deposit } \\
\text { of Banks }\end{array}$ & \% Increase/Decrease \\
\hline 2000 & 838.5 & 59 \\
2001 & $1,017.1$ & 50 \\
2002 & $1,226.6$ & 42 \\
2003 & $1,415.8$ & 26 \\
2004 & $1,814.7$ & - \\
2005 & $2,469.0$ & 38 \\
2006 & $3,412.3$ & 117 \\
2007 & $5,357.2$ & 252 \\
2008 & $8,702.0$ & 305 \\
2009 & $9,989.8$ & 339 \\
2010 & $10,837.1$ & \\
\hline
\end{tabular}

Source: NDIC Annual Reports of 2001, 2002, 2008 \& 2010

According to Table.2, the total deposit base of commercial banks increased by N943.3B (38\%), N2,888.2B (117\%), and N6233.0B (252\%) in 2006, 2007 and 2008 respectively when compared with the total deposit base of commercial banks in 2005 before the banking sector consolidation. Total deposit base of commercial banks increased by N7, 520.8B (305\%), N8, 368.1B (339\%) in 2009 and 2010 respectively when compared to the total base of commercial banks in 2005 .

\section{i. Loans and Advances to Real Sector of the Economy}

Sectoral distribution of commercial banks loans and advances to the real sector of the Nigerian Economy (see Table.1) increased by N173,131.2 Million from N573,131.9 Million in 2005 to N746,663.1 in 2006 indicating a 30\% increase one year after the banking sector consolidation in 2005.

In 2007 and 2008, commercial banks allocation of their loans and advances to the real sector of Nigerian Economy increased by N554,735.9 Million and N1,312,964.2 Million respectively when compared 
with that of 2005. In 2009 and 2010, Commercial Banks allocation of their Loans and Advances to the real sector of Nigerian Economy increased by N7,825,062 Million and N9,200,927 Million respectively when compared with Commercial Banks allocation of Loans and Advances to the real sector of the economy in 2005. This translates to an increase of $1365 \%$ and $1605 \%$ in 2009 and 2010 respectively when compared to that of 2005.

\section{ii. Deposit Base of Commercial Banks.}

Commercial banks total deposits increased by N943.3Billion from N2, 469.0 Billion in 2005 to N3, 412.3 billion in 2006 (see Table.2) representing an increase of $38 \%$ barely one year after the banking sector consolidation in 2005. In 2007 and 2008, commercial banks deposit base increased by N2, 888.2 billion and N6, 233.0 billion representing $117 \%$ and $252 \%$ respectively when compared with the total deposit base of commercial banks in 2005.

In 2009 and 2010, commercial banks deposit base increased by N7, 520.8 billion and N8, 368.1 billion representing $305 \%$ and $339 \%$ respectively when compared with the total deposit base of commercial banks in 2005.

\section{i. Sectoral Allocation of Commercial Banks Loans and Advances to Real Sector of the Economy.}

In 2007 and 2008, commercial banks sectoral allocation of their loans and advances to the real sector of the Nigerian economy increased by N554, 735.9 Million and N1, 312,964.2 Million or by $97 \%$ and 229\% respectively. In 2009 and 2010, commercial banks allocation of their loans and advances to the real sector of Nigerian economy went up by N7, 825,062 Million and N9, 200,927 Million or 1365\% and 1605\% respectively when compared to commercial banks total allocation of their loans and advances to the real sector of the economy in 2005.

It follows from this analysis that the banking sector consolidation of 2005 led to increase in sectoral allocation of commercial banks total loans and advances to the real sector of the Nigerian economy from $30 \%$ in $2006,97 \%$ in $2007,229 \%$ in 2008 , and $1365 \%$ and $1605 \%$ in 2009 and 2010 respectively.

\section{ii. Increase in Deposit Base of Commercial Banks.}

An analysis of key macroeconomic indicators from NDIC Annual Reports (see Table.2) revealed that commercial banks deposit base increased by N2, 888.2 Billion and N6, 233.0 Billion in 2007 and 2008 respectively after the banking sector consolidation in 2005 . This represents an increase of $117 \%$ and $252 \%$ in 2007 and 2008 respectively.

In 2009 and 2010, commercial banks deposit base increased by N7, 520.8 Billion and N8, 368.1 Billion representing $305 \%$ and $339 \%$ respectively. It goes without saying that from the analysis of data from NDIC annual reports that the deposit of commercial banks increased considerably over the five years period (2006 2010) after the banking sector consolidation of 2005.

This confirms Sanusi (2010) position that the long term reforms of the financial sector being carried out by CBN that apart from financial sector stability, the financial system will assist in growing the real sector of the economy. The findings of this study is in line with Somoye (2009) argument that the aim of banking sector reform through consolidation is to enhance its competiveness and capacity to play a fundamental role of financing investment. The result of this study has shown that the banking sector consolidation has increased the capacity of commercial banks to fund investment in the real sector of the economy by increasing their allocation of loans and advances to the real sector over the five year $(2006-2010)$ period following the consolidation exercise in 2005. The findings of this study also agree with Oboh (2005) observation that financial intermediation is an area that commercial banks have professional expertise of matching the interest of depositors with those of borrowers by providing more or less a coordination of functions for the two groups.

\section{Conclusion}

There was considerable increase in the volume of loans and advances commercial banks extended to the real sector of Nigerian economy over the past five years after the banking sector consolidation exercise in 2005. Sectoral distribution of commercial banks loans and advances to the agriculture, manufacturing, and mining sectors of the economy which are considered to be the real sector of the economy increased considerably from 2006 to 2010 when compared to their position in 2005 before the banking sector consolidation. There was considerable improvement in the volume of commercial banks loans and advances extended to agriculture, manufacturing, and mining industries which are considered to be the real sector of Nigerian economy for the past five years (2006 -2010) after the banking sector consolidation in 2005. The Federal Government through the CBN should encourage this trend to continue. Agriculture, forestry and fishery were classified under one heading in sectoral distribution of commercial banks loans and advances and the total amount allocated to this sector was quite lower than that of manufacturing over the five years period after the banking sector 
consolidation. The federal government should encourage the commercial banks through the supervisory role of the Central Bank of Nigeria (CBN) to extend more credits to the agricultural sector. This will help to reduce the present rate of unemployment as the Agricultural sector is capable of employing more than fifty percent of the unemployed people in the country. Commercial banks should be encouraged to extend more credits to the SMEs. Special attention should be paid to this sector and provision should be made for them in the returns of sectoral distribution of commercial banks loans and advances in CBN statistical bulletins. The emerging economies of Japan, Taiwan, Singapore, Honkong, and Malaysia are driven by SMEs.

The N200 Billion Small and Medium Scale Enterprises Guarantee Scheme (SMECGS) established by CBN in 2010 to provide guarantee on loans extended to SMEs by banks is a step in the right direction. This scheme should be properly monitored by CBN to ensure that credit facilities are extended to the real people that are involved in Small and Medium Scale enterprises.

4. The Federal Government through the CBN should encourage commercial banks to extend more credits to the Real Sector of the Nigerian economy rather than concentrating more on general trade and commerce. It is the real sector of the economy that drives the economy and will create employment for the teeming number of unemployed Nigerians.

\section{References}

[1]. Adegbaju A.A \& Olokoyo F.O (2008) Recapitalization and Banks Performance; A case study of Nigerian Banks, African Economic and Business Review 6(1)

[2]. Adeyemi, K. S. (2005). Banking Consolidation in Nigeria: Issues and Challenges, Union Digest, 9(3 \& 4).

[3]. Akhavin, J. D., Berger, A. W., and Humphrey, D. B. (1997). The effects of mega mergers on efficiency and prices: Evidence from a bank profit function. Review of Industrial Organization: 12.

[4]. C.B.N, (2006); Statistical Bulletin Vol. 17, December 2006.

[5]. C.B.N, (2010): Statistical Bulletin. December 2010.

[6]. C.B.N, (2010): Annual Reports

[7]. C.B.N, (2004) Consolidation of Nigeria's Banking Industry “Fourth Annual Monetary Conference Proceedings, 18th - 19" November 2004.

[8]. Fukuyama, H. (1993). Technical and Scale Efficiency in Japanese Commercial Banks: A Non-Parametric Approach, Applied Economics, 25: 1101-12.

[9]. Hall, M. J. B. (1999). Japan Big Bang: The Likely Winners and Losers. Journal of International Banking Law, 7: 204-16.

[10]. Ikpefan, ochei ailemen (2012) Post-Consolidation Effect of Mergers and Acquisitions on Nigeria Deposit Money Banks, European Journal Of Business And Management Www.Iiste.Org 14 (16)

[11]. Lin, J. (2009). -Walk, Don't Runl, The www.economist.com/businessfinance/economicsfocus/displaystory.cfm?st ory id=13986299. Accessed November, 2011

[12]. Mckillop, D., Glass, J. C., and Morikawa, Y. (1996). The Composite Cost Function and Efficiency in Giant Jappanese Banks. Journal of Banking and Finance, 20: 1651-71.

[13]. Nigeria Deposit Insurance Corporation (N. D. I. C) (2010) 20 Years of Deposit insurance in Nigeria, Published by NDIC

[14]. N.D.I.C Annual Report \& Statement of Accounts Various Years

[15]. Ningi S.I. and Dutse A.Y. (2008) Impact of Bank Consolidation Strategy on the Nigerian Economy African Economic and Business Review 6(2)

[16]. Oboh, G. A. T. (2005). Selected Essays on Contemporary Issues in the Nigerian Banking System,_Ibadan University Press.

[17]. Sanusi, Lamido (2011). Bank in Nigeria and National Economic Development: A critical Review. Being a keynote Address at the seminar on 'Becoming an Economic Driver While Applying Banking Regulations', by Canadian High Commission in Joint Collaboration with the Chartered Institute of Bankers of Nigeria (CIBN) and Royal Bank of Canada (RBC) on March 2011.

[18]. Sanusi, Lamido (2010). Global Financial Meltdown and the Reforms in the Nigeria Banking Sector; Being the full text of a Public Lecture delivered at the Convocation Square, Abubakar Tafawa Balewa University Bauchi, December 10, 2010.

[19]. Soludo, C. (2004). Consolidating the Nigerian Banking industry to meet the Development Challenges of the $21^{\text {st }}$ Century. Being an address delivered to the Special Meeting of Bankers' Committee, held on July 6, at the CBN Headquarter Abuja

[20]. Soludo, C. (2004). Consolidation and Strengthening of Banks Speech delivered at the Meeting of Bankers Committee $6^{\text {th }}$ August 2004.

[21]. Somoye, R.C.O, (2008); The Performance of Commercial Banks in Post consolidation period in Nigeria; An Empirical Review; European Journal of Economics, Finance and Administrative Sciences Issue 14 